International Journal of Business Economics (IJBE)

Vol, 2 Issue 2, pp 86-98, March - August 2021

http://jurnal.umsu.ac.id/index.php/ijbe

eISSN 2686-472X

ORIGINAL ARTICLE

\title{
Effect of Moderation of Work Motivation on the Influence of Organizational Culture on Organizational Commitment and Employee Performance
}

\author{
Jufrizen $^{1 *}$, Mukmin ${ }^{1}$, Dinda Nurmala ${ }^{1}$, Hanifah Jasin ${ }^{1}$
}

\begin{abstract}
This study aims to analyze the influence of organizational culture on employee performance, the influence of organizational culture on organizational commitment, the influence of organizational culture on employee performance through organizational commitment and the role of motivation in moderating the influence of organizational culture on employee performance. This type of research is an associative research using saturated sampling where all members of the population are sampled as many as 85 employees. Data collection techniques are used by questionnaires and data analysis techniques are used by Partial Least Square (SmartPls). Research results show that: (1) the influence of organizational culture on employee performance is positive and significant; (2) the influence of organizational culture on positive and significant organizational commitment; (3) the effect of organizational commitment on positive and significant performance; (4) organizational commitment acts as a mediator on the influence of organizational culture on employee performance; (5) motivation does not act as a moderation on the influence of organizational culture on employee performance
\end{abstract}

\section{Keywords: Organizational Culture, Organizational Commitment,} Performance, Motivation

DOI :https://doi.org/10.30596/ijbe.v2i2.6710

JEL Classification O15, L84, L25, J21

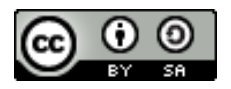

Published byInternational Journal of Business Economics (IJBE), Indonesia | Copyright (C) 2021 by the Author(s) | This is an open access article distributed under the Creative Commons Attribution License http://creativecommons.org/licenses/by/4.0), which permitsunrestricted use, distribution, and reproduction in any medium, provided the original work is properly cited.

Cite this article as:

Jufrizen, J., Mukmin, M., Nurmala, D., \& Jasin. H. (2021).Effect of Moderation of Work Motivation on the Influence of Organizational Culture On Organizational Commitment and Employee Performance. International Journal of Business Economics (IJBE), 2(2), 86-98.

Faculty of Economic and Business, Universitas Muhammadiyah Sumatera Utara Jln. Kapten Muchtar Basri No. 3 Medan 20238, Indonesia

*Corresponding Author:jufrizen@umsu.ac.id 


\section{International Journal of Business Economics (IJBE)}

Vol, 2 Issue 2, pp 86-98, March - August 2021

http:/ /jurnal.umsu.ac.id/index.php/ijbe

eISSN 2686-472X

\section{INTRODUCTION}

In a government institution, employee performance is very important to support and help achieve the work targets of each employee, therefore the institution must always control its employees whether their employees are working well in order to be able to improve performance more effectively and efficiently for achieve their work targets. Effective and efficient performance improvement by each employee is one of the most coveted by the leadership of the institution. Employees will get an award for every performance they provide with their abilities, skills, and self-motivation. However, superiors play a very important role in planning, implementing, and controlling an organization. In this case, superiors must have an important role in their efforts to manage their employees in improving their performance. Organizations need to pay special attention to the achievements obtained by employees by providing rewards (prizes), rewards, and (rewards) and motivation to work enthusiastically, have high responsibility for their duties, so that an organization will easily fulfill the planned goals (Lina, 2014).

Employee performance is influenced by several factors such as organizational culture factors, organizational commitment and work motivation, where this organizational culture becomes a habit and tradition that must be done and carried out by each employee of the organization to show one of the performance on the organization. The performance is shown by individuals is often used to refer to individual achievements and levels of success in carrying out organizational activities. Performance is the work result of employees both in terms of quality and quantity in carrying out and completing tasks assigned to the employee by the superior or their leader based on their role in the company (Jufrizen, 2016).

According to Busro (2018) says about organizational culture is a shared perception is held by organizational members as an organizational value system is adhered to by organizational members, which then influences the way the organization members work and behave. Each organization has a different culture that they apply in the organization. In fact, the organizational culture adopted is not implemented and carried out properly, there are still many employees who have not yet carried out the organizational culture adhered to in the Regional Office of the Directorate General of Treasury, North Sumatra Province. But several factors besides organizational culture, there are several more factors that can affect employee performance, namely work commitment and motivation because some of these factors can improve employee performance in achieving the goals of an organization.

Therefore organizational commitment is also very important in an institution to realize the goals of the institution, commitment can be realized if individuals in the organization carry out their rights and obligations in accordance with their respective duties and functions in the organization, because for the achievement of organizational goals is the result of work. All members of the organization who are collective (Kurniawan, 2013). Meanwhile, according to (Mathis \& Jackson, 2000) providing a definition of organizational commitment is the degree to which employees believe and accept organizational goals and will remain or will not leave the organization. Motivation also determines the results of employee performance, if there is a decrease in work motivation of each employee, the employee cannot deliver their performance results optimally and efficiently. Motivation is employee motivation or employee mental attitude that leads or encourages behavior toward the achievement of needs that provide satisfaction (Hasibuan, 2003). Basically, the motivational factors are grouped into two 


\section{International Journal of Business Economics (IJBE)}

Vol, 2 Issue 2, pp 86-98, March - August 2021

http:/ /jurnal.umsu.ac.id/index.php/ijbe

eISSN 2686-472X

groups, namely internal factors and external factors. Internal factors (personal characteristics) in motivation include needs, wants and expectations that are contained in the person. External factors (company characteristics) consist of work environment, salary, working conditions, and company policies, and work relationships such as awards, promotions, and responsibilities (Mangkunegara, 2005).

However, in this study, among the factors above, the writers focus on four factors to be studied in this study, namely organizational culture on employee performance which is mediated by organizational commitment and moderated by work motivation. A phenomenon that often occurs in every government institution, the lack of employee performance levels due to the implementation of a poor organizational culture at the Regional Office of the Directorate General of Treasury of North Sumatra Province is not implemented. Within a government agency it is also very much determined by the internal environmental conditions and organizational behavior that does not want to commit to the organization, a phenomenon that often occurs resulting in good performance in an institution that can be damaged either directly or indirectly by unwilling employee attitudes doesn't want to committed to the organization (Anggraeni, 2016). Employees in a government agency can be motivated by providing what the employees need and want.

Organizational culture is a system of values and norms that are shared by members of the organization, if employees see that the values and norms are very important and meaningful to them and the system is very valuable, with this one of the supporting employees are doing their work comfortably and supporting the performance results they provides. Besides culture, organizational commitment is very important to support their performance in the first work contract when entering the world of work, from that commitment the institution can assess how much each employee wants to see their organization progress and achieve all the goals are desired by the organization. Leaders must always control each member; they need to be motivated with support and all kinds of motivation so that their performance is better, and always stay in harmony with their subordinates to create an organizational culture and a very comfortable work environment for better performance than before.

Organizational culture is a system of values and norms that are shared by members of the organization, if employees see that the values and norms are very important and meaningful to them and the system is very valuable, with this one of the supporting employees are doing their work comfortably and supporting the performance results they provides.

Based on theoretical studies and previous research, it is stated that. The results showed that organizational culture has a positive influence on performance (Nystrom, 1993); (Gultom, 2014); (Jufrizen, et al., 2017) ; (Jufrizen, 2017); (Muis, Jufrizen, \& Fahmi, 2018) dan (Andayani \& Tirtayasa, 2019). Research by Fey \& Denison (2000) shows that a well-developed and orderly organizational culture in the company will have an effect on improving employee performance. So it can be concluded that the positive influence of organizational culture on improving employee performance.

Organizational culture is very important to have a sense of comfort in the work environment, as well as very important commitment for any government agency employees who have a commitment to themselves to quickly complete work contracts properly will be able to bring the institution to its goal. Then it can be hypothesized that:

H1: Organizational culture affects employee performance 


\section{International Journal of Business Economics (IJBE)}

Vol, 2 Issue 2, pp 86-98, March - August 2021

http:/ /jurnal.umsu.ac.id/index.php/ijbe

eISSN 2686-472X

It was also explained by (Robbins \& Judge, 2013) who state that indicators of organizational culture formation are attention to detail, people orientation, team oriented, aggressiveness, and stability. This means that through a process that has been regulated by the organization, and applying the principles of organizational culture, it is hoped that it can form a strong organizational commitment. This means that organizational culture has a positive effect on organizational commitment. Meanwhile, the research conducted shows that organizational culture has a positive effect on organizational commitment (Jandeska \& Maria, 2005), (Jufrizen et al., 2017) and (Muis et al., 2018). Then it can be hypothesized that:

H2: Organizational culture affects employee organizational commitment

Organizational commitment is very important to support their performance in the first employment contract when they enter the world of work, from that commitment the institution can assess how much each employee wants to see their organization progress and achieve all the goals are desired by the organization. The results of research is conducted by (Pahmi et al., 2011) show that organizational commitment has a positive effect on employee performance. The results show in his research that organizational commitment has a positive effect on employee performance (Suwardi \& Utomo, 2011) and (Jufrizen, Gultom, Sitorus, Sari, \& Nasution, 2018) and (Adhan, Jufrizen, Prayogi, \& Siswadi, 2020). Based on the theory above, it can be hypothesized that:

H3: Organizational commitment affects employee performance

Research is conducted by Hakim (2015) shows that organizational culture has a positive and significant influence on organizational commitment and employee performance. It also found that organizational commitment has a positive and significant effect on employee performance, and organizational commitment has a significant role as a mediating variable between organizational culture and employee performance. Research is conducted by Soepardjo \& Seno (2014) shows that organizational culture has a significant influence on employee performance. Organizational commitment has a significant effect on employee performance. Organizational culture factors and organizational commitment have a simultaneous or joint effect on employee performance. Furthermore, the results of the study concluded that the Organizational Commitment variable had a positive effect on employee performance. This is in accordance with the hypothesis which states that organizational commitment has an effect on employee performance (Gusty \& Seno, 2018). Based on the theory above, it can be hypothesized that:

H4: Motivation plays a role as moderation of organizational culture on employee performance

Leaders must always control each member; they need to be motivated with support and all kinds of motivation so that their performance is better, and always stay in harmony with their subordinates to create an organizational culture and a very comfortable work environment for better performance than before. The opinion of Hutomo \& Akhmad (2015) in conducting research on the moderating effect of the influence of organizational culture on performance shows that motivation moderates the influence of organizational culture on employee performance. Research by (Dian, 2017) shows good motivation results show good performance. Based on the theory above, it can be hypothesized that: 


\section{International Journal of Business Economics (IJBE)}

Vol, 2 Issue 2, pp 86-98, March - August 2021

http://jurnal.umsu.ac.id/index.php/ijbe

eISSN 2686-472X

H5: Organizational commitment acts as a mediator for organizational culture on employee performance.

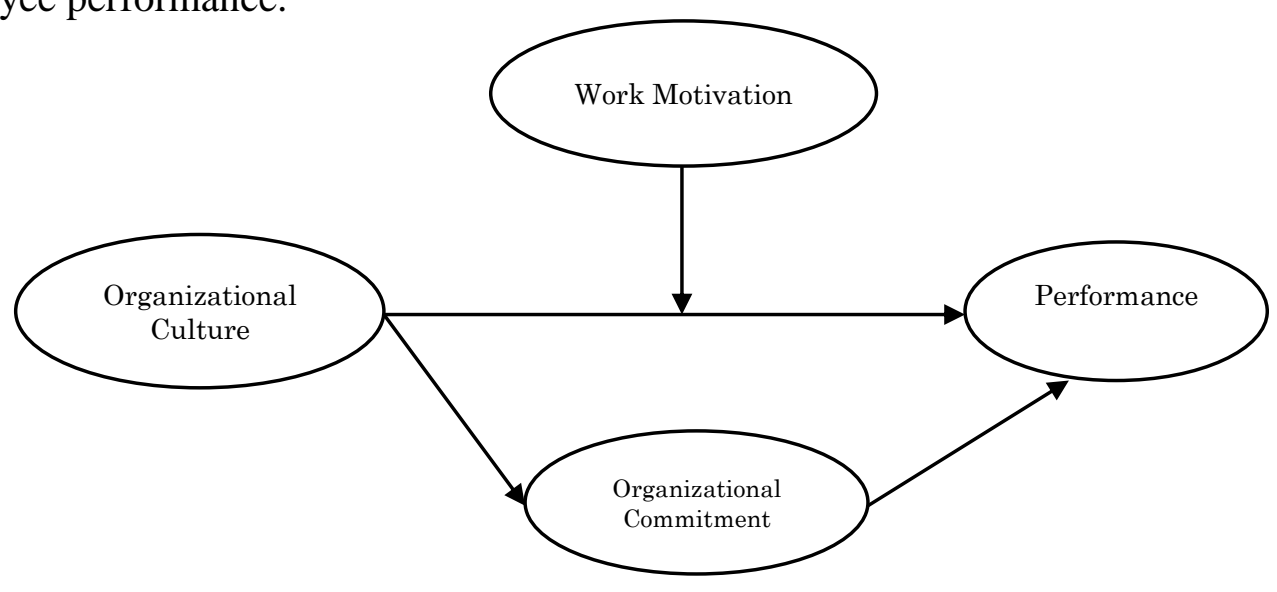

Figure 1. Conceptual Framework

\section{METHOD}

This study uses an explanatory research approach, which aims to explain the causal relationship between the research variables and the testing hypothesis (Nasution, et al., 2020). The approach used is an associative approach. The population of this study was all employees of the Regional Office of the Directorate General of Treasury in North Sumatra Province, totaling 85 people. The sampling technique for nonprobability sampling is saturated sampling in which all members of the population are sampled (Sugiyono, 2010). In this study, the sample that will be used is the number of the population of the employees of the Regional Office of the Directorate General of Treasury, North Sumatra Province. Data collection techniques in this study using a list of questions or questionnaires. This study uses partial regression analysis (Partial Least Square / PLS) to test the hypothesis proposed in this study. Each hypothesis will be analyzed using SmartPLS 3.0 software to test the relationship between variables.

\section{RESULTSAND DISCUSSION}

Measurement Model Analysis

The statistics used in composite reliability are the composite reliability values above 6.0, indicating that the construct has high reliability or reliability as a measuring tool. A limit value of 0.6 and above means acceptable and above 0.8 and 0.9 means very satisfying (Juliandi, 2018).

Tabel 1. Result of Composite Reliability

\begin{tabular}{cc}
\hline & Composite Reliability \\
\hline $\mathrm{X}$ & 0.901 \\
\hline $\mathrm{Z} 2$ & 0.904 \\
\hline $\mathrm{Y}$ & 0.933 \\
\hline $\begin{array}{c}\text { Organizational Culture } \\
\text { Motivation }\end{array}$ & 0.874 \\
\hline
\end{tabular}

The conclusion of testing composite reliability is variable $\mathrm{X}$ is reliable, because the value of composite reliability $\mathrm{X}$ is $0.901>0.6$. The variable $\mathrm{Z} 2$ is reliable, because the composite reliability value of $\mathrm{Z} 2$ is $0.904>0.6$. The variable $\mathrm{Y}$ is reliable, because the 


\section{International Journal of Business Economics (IJBE)}

Vol, 2 Issue 2, pp 86-98, March - August 2021

http:/ /jurnal.umsu.ac.id/index.php/ijbe

eISSN 2686-472X

value of the composite reliability $\mathrm{Y}$ is $0.933>0.6$. And the variable $\mathrm{X} * \mathrm{Z} 2$ is reliable, because the value of the composite reliability $\mathrm{X} * \mathrm{Z} 2$ is $0.874>0.6$.

Average Variance Extracted (AVE) describes the amount of variance that can be explained by items compared to the variance is caused by measurement error. The default is if the AVE value is above 0.5, it can be said that the construct has a good convergent validity. This means that the latent variable can explain the average of more than half the variance of the indicators.

Table 2. Result of Average Variance Extracted (AVE)

\begin{tabular}{cc}
\hline & Composite Reliability \\
\hline $\mathrm{X}$ & 0.535 \\
\hline $\mathrm{Z} 2$ & 0.544 \\
\hline $\mathrm{Y}$ & 0.638 \\
\hline Organizational Culture *Work Motivation & 0.152 \\
\hline
\end{tabular}

The conclusion of the Average Variance Extracted test is that the Variable $\mathrm{X}$ is reliable, because the Average Variance Extracted $\mathrm{X}$ value is $0.535>0.5$. The variable $\mathrm{Z} 1$ is reliable, because the Average Variance Extracted $\mathrm{Z} 1$ value is $0.544>0.5$. The variable $\mathrm{Y}$ is reliable, because the Average Variance Extracted $\mathrm{Y}$ value is $0.638>0.5$ and the variable Organizational Culture*Work Motivation is not reliable, because the Average Variance Extracted Organizational Culture*Work Motivation is $0.152<0.5$.

Discriminant validity is the extent to which a construct is completely different from other constructs (a construct is unique) (Juliandi, 2018). The best new measurement criterion is looking at the Heretroit-Monotrait Ratio (HTMT) value. If the HTMT value is $<0.90$, then a construct has good discriminant validity according to (Juliandi, 2018).

Table 3. Descriminant Validity

\begin{tabular}{ccccc}
\hline & \multicolumn{3}{c}{ Discriminant Validity } \\
\cline { 2 - 4 } & $\mathrm{X}$ & $\mathrm{Z} 2$ & $\mathrm{Y}$ & $\begin{array}{c}\text { Organizational Culture*Work } \\
\text { Motivation }\end{array}$ \\
\hline $\mathrm{X}$ & & 0.343 & \\
\hline $\mathrm{Z} 2$ & & & 0.220 \\
\hline $\mathrm{Y}$ & 1.004 & 0.259 & \\
\hline $\begin{array}{c}\text { Organizational } \\
\text { Culture*Work Motivation }\end{array}$ & 0.259 & 0.468 & \\
\hline
\end{tabular}

The conclusion of the Heretroit-Monotrait Ratio (HTMT) test is that the variable of organizational culture on work motivation has a Heretroit-Monotrait Ratio value of 0.343 $<0.915$, meaning that the discriminant validity is good, or really from the construction. The variable of organizational culture on the performance of the Heretroit-Monotrait Ratio value is $1.004>0.90$, which means that the discriminant validity is not good, or is not completely different from other constructs (the construct is not unique). The variable of organizational culture on organizational culture*work motivation, the value of Heretroit Monotrait Ratio $0.259<0.90$, means that the discriminant validity is good, or really from the construction (the construct is unique). Variable organizational culture*work motivation on work motivation Heretroit Monotrait Ratio value $0.468<0.90$ it means that the discriminant validity is good, or really from the construction (the construct is unique). Organizational culture variable*work motivation on the performance value of Heretroit Monotrait Ratio $0.220<0.90$ it means that the discriminant validity is good, or really from 


\section{International Journal of Business Economics (IJBE)}

Vol, 2 Issue 2, pp 86-98, March - August 2021

http://jurnal.umsu.ac.id/index.php/ijbe

eISSN 2686-472X

the construction (the construct is unique) and the performance variable on work motivation, Heretroit Monotrait Ratio value of $0.259<0.90$, means that the discriminant validity is good, or really from the construction (the construct is unique).
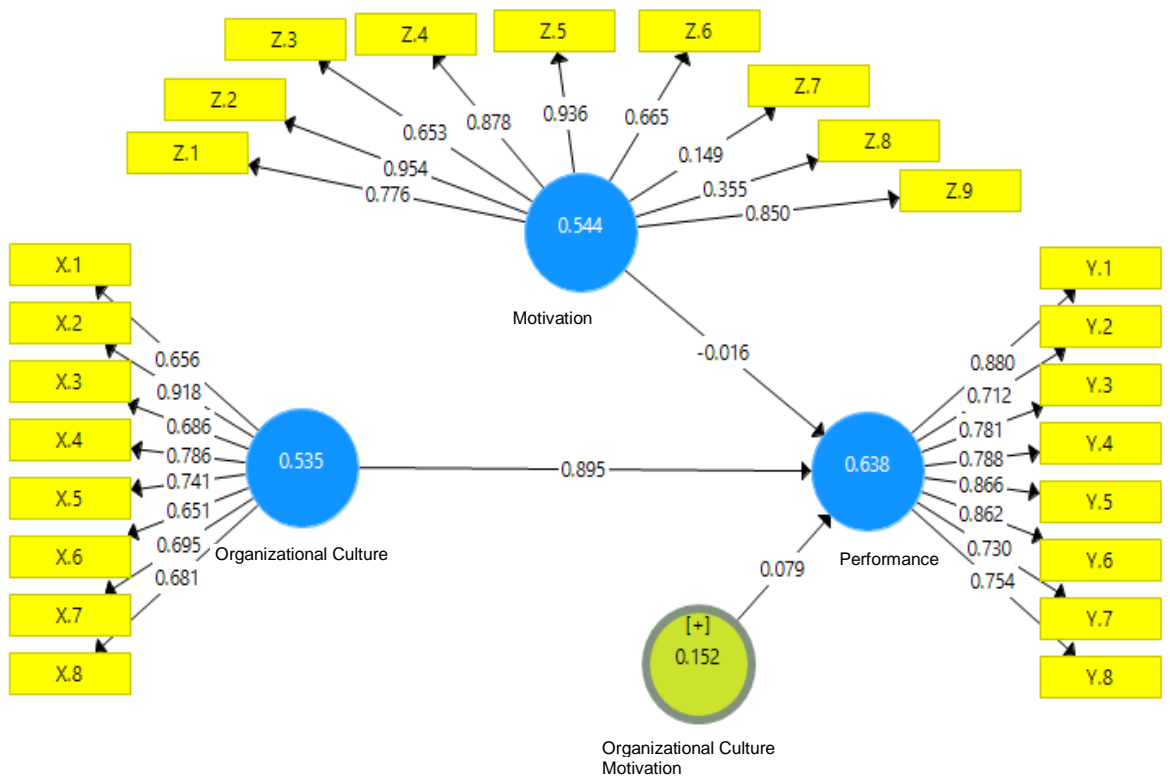

Figure 2. Standardized Loading Factor Inner and Outer Model

\section{Structural Model Analysis (Inner Model)}

The definition of R-Square is a measure of the proportion of the variation in the value of the affected (endogenous) variable which can be explained by the variables that influence it (exogenous). This is useful for predicting whether a model is good / bad (Juliandi, 2018).

Table 4. R-Square

\begin{tabular}{ccc}
\hline & R-Square & R-Square Adjusted \\
\hline $\mathrm{Y}$ & 0.841 & 0.835 \\
\hline
\end{tabular}

The conclusion from testing the r-square value on is that the R-Square Adjusted for the Path model using moderator variables is 0.835 . This means that the variable ability of organizational culture, work motivation and organizational culture*work motivation (interaction of organizational culture with work motivation) in explaining performance is $83.5 \%$, thus the model is classified as substantial. F2 effect size (F-Square) is a measure used to assess the relative impact of an influencing (exogenous) variable on the affected (endogenous) variable. The change in $\mathrm{R} 2$ value when certain exogenous variables are removed from the model can be used to evaluate whether the omitted variables have a substantive impact on endogenous constructs (Juliandi, 2018). 


\section{International Journal of Business Economics (IJBE)}

Vol, 2 Issue 2, pp 86-98, March - August 2021

http://jurnal.umsu.ac.id/index.php/ijbe

eISSN 2686-472X

Table 5. F-Square

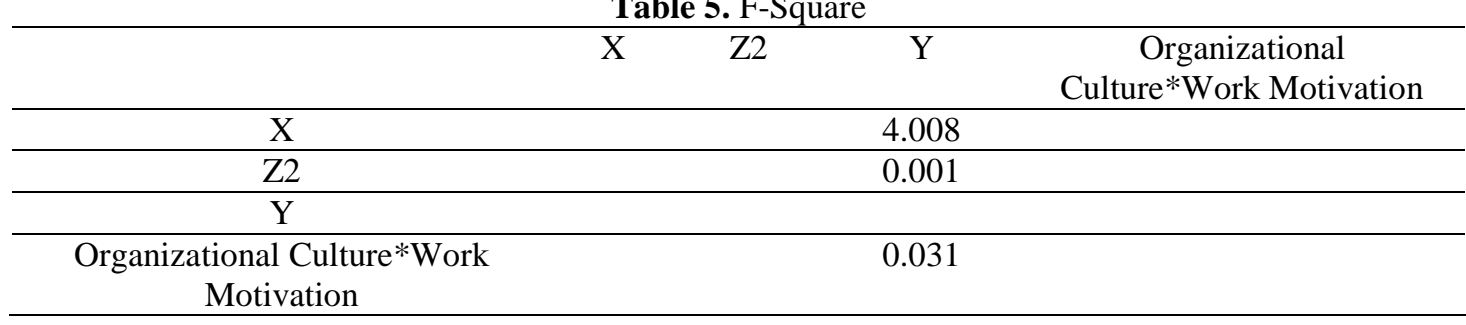

From the table above it is known that the performance variable on organizational culture has a value of $\mathrm{f} 2=4.008$, so the strong effect of exogenous variables on endogenous. The performance variable on work motivation has a value of $\mathrm{f} 2=0.001$, hence the small effect of exogenous variables on endogenous. And the variable performance on organizational culture* work motivation has a value of $f 2=0.031$, so the small effect of exogenous variables on endogenous.

Table 6. Direct Effect

\begin{tabular}{ccccccc}
\hline & $\begin{array}{c}\text { Original } \\
\text { Sample (O) }\end{array}$ & $\begin{array}{c}\text { Sample } \\
\text { Mean (M) }\end{array}$ & $\begin{array}{c}\text { Standard } \\
\text { Deviation } \\
(\text { STDEV })\end{array}$ & $\begin{array}{c}\text { T Statistics } \\
(\mid \mathrm{O} / \text { STERR } \mid)\end{array}$ & t table & $\begin{array}{c}\text { P- } \\
\text { Value }\end{array}$ \\
\hline $\mathrm{X}->\mathrm{Y}$ & 0,895 & 0,891 & 0,043 & 20,695 & 1,982 & 0.000 \\
\hline $\mathrm{Z} 2->\mathrm{Y}$ & $-0,016$ & -0.014 & 0,046 & 0,355 & 1,982 & 0.723 \\
\hline $\mathrm{X}^{*} \mathrm{Z} 2->\mathrm{Y}$ & 0.079 & 0.057 & 0,113 & 0,703 & 1,982 & 0,482 \\
\hline
\end{tabular}

The conclusion of the direct effect value is $\mathrm{X}$ to $\mathrm{Y}$ : path coefficient $=20.695>\mathrm{T}$ table $=1.982$ meaning, the effect of $\mathrm{X}$ on $\mathrm{Y}$ is significant. $\mathrm{Z} 2$ to $\mathrm{Y}$ : Path coefficient $=$ $0.355<\mathrm{T}$-Table $=1.982$ means that the effect of $\mathrm{Z} 2$ on $\mathrm{Y}$ is not significant. $\mathrm{X} * \mathrm{Z} 2$ to $\mathrm{Y}$ : Path coefficient $=0.703<\mathrm{T}$-Table $=1.982$, meaning that the moderator variable $(\mathrm{Z} 2)$ does not moderate the effect of an endogenous variable (free) on the endogenous (dependent) variable.

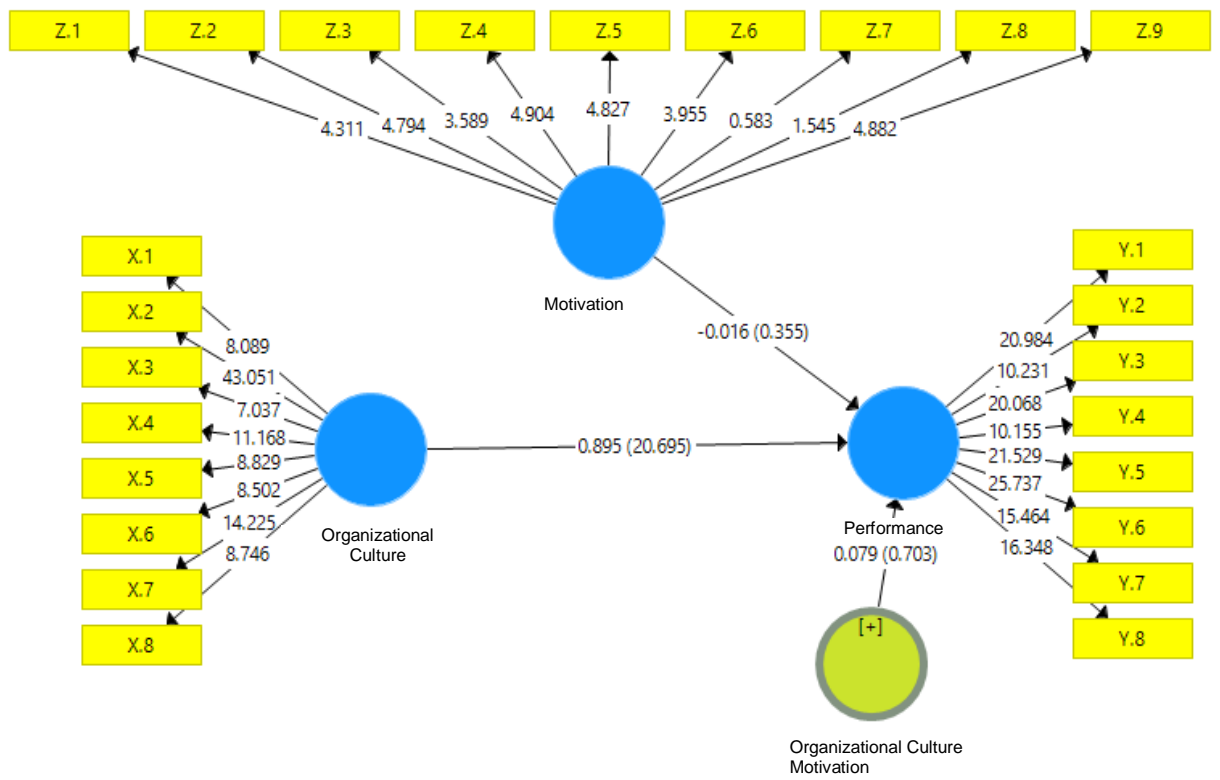

Figure 6. T-Value Inner and Outer Model 


\section{International Journal of Business Economics (IJBE)}

Vol, 2 Issue 2, pp 86-98, March - August 2021

http:/ /jurnal.umsu.ac.id/index.php/ijbe

eISSN 2686-472X

The $t$ test that is carried out is the result of the $t$ test from the bootstrap calculation. The $t$ test results in the image above will then be compared with the $t$ table value.

\section{Discussion}

\section{The Influence of Organizational Culture on Performance}

From the results of data analysis, it is known that organizational culture has a positive and significant effect on performance. This means that organizational culture is an important factor that affects performance, because by carrying out an organizational culture that is applied to each employee properly, it will create a comfortable working environment, with a comfortable working environment that will create an increase in employee performance. This indicates that the organizational culture must be implemented very well to maintain company values and maintain a comfortable work environment for better performance results. The results of this study are supported by several researchers who also say that a well-developed and orderly organizational culture in the company will have an effect on increasing employee performance, which is positive and significant (Fey \& Denison, 2000); (Parry \& Thomson, (2003) (Nystrom, 1993); (Gultom, 2014); (Jufrizen et al., 2017); (Jufrizen, 2017); (Muis et al., 2018) and (Andayani \& Tirtayasa, 2019)

\section{The Influence of Organizational Culture on Organizational Commitment}

From the results of data analysis, it is known that organizational culture has a positive and significant effect on organizational commitment. This means that an organizational culture that is adopted and carried out strongly by each employee can provide quality and will have a positive impact on other members of the organization, namely reducing the tendency of employees to leave the organization, from such a thing will create organizational commitment. This indicates that every employee must carry out an organizational culture with values that are instilled in the company every day, in order to create commitment within employees. The results of this study are supported by several researchers who also say that the stronger the organizational culture, the higher the organizational commitment in employees (Taurisa \& Ratnawati, 2012); (Fauzi, Warso, \& Haryono, 2016); (Jandeska \& Maria, 2005) and (Muis et al., 2018).

\section{The Influence of Organizational Commitment on Performance}

From the results of data analysis, it is known that organizational commitment has a positive and significant effect on performance. This means that the higher the employee's organizational commitment, the impact on the employee's performance improvement. This indicates that every employee must have a commitment in himself to improve performance and can achieve the goals of the organization, with commitment that employees will be more responsible for their work compared to employees who are not committed. The results of this study are supported by several researchers who also state that organizational commitment has a positive and significant effect on performance (Suwardi \& Utomo, 2011); (Bunga, 2012). Likewise, several other research results show in their research that organizational commitment has a positive and significant effect on employee performance (Pahmi et al., 2011), (Jufrizen et al., 2018) and (Adhan et al., 2020). 


\section{International Journal of Business Economics (IJBE)}

Vol, 2 Issue 2, pp 86-98, March - August 2021

http:/ /jurnal.umsu.ac.id/index.php/ijbe

eISSN 2686-472X

\section{The Influence of Organizational Culture on Performance Mediated by Organizational Commitment}

From the results of data analysis, it is known that organizational commitment mediates the influence of organizational culture on performance. This means that if organizational commitment arises in each employee, it will indirectly has a very good and positive impact on the employees themselves and a reflection of the company itself, because when the employee is committed, the employee will automatically every day carry out the organizational culture happily which has an impact on the company's outstanding performance to achieve it. The results of this study are supported by several researchers who say the influence of organizational culture on performance is mediated by organizational commitment, saying that organizational culture has a very positive and significant effect on performance and is mediated by organizational commitment (Nurdin \& Acep, 2016); (Tarjono \& Asep, 2018), (Soepardjo \& Seno, 2014), (Gusty \& Seno, 2018).

\section{The Influence of Organizational Culture on Performance Moderated by Work Motivation}

From the results of data analysis, it is known that motivation does not moderate the influence of organizational culture on performance. This means that direct motivation has no close relationship (not related) at all to organizational culture. Motivation has a strong attachment to employee performance. High motivation will result in high performance, fulfillment of the needs that motivate employees in the workplace to improve employee work performance in accordance with their respective contributions. Thus, if the needs that become employees' work motivation are increasingly fulfilled, the employee's performance will be even higher. The results of this study are supported by several other studies which are inconsistent showing that work motivation does not moderate the effect of organizational culture on performance (Dian, 2017); (Hutomo \& Akhmad, 2015) dan (Sutarno, 2011). The results of this study are also supported by several studies that are in line, stating that work motivation positively moderates or strengthens the influence of organizational culture on organizational performance. This shows that every interaction of organizational culture with work motivation increasing by one unit will result in increasing organizational performance (Kadek \& Widanaputra, 2017); (Widyastuti \& Hasan, 2015).

\section{Implications}

The results of this study are expected to provide both theoretical and managerial implications, the following are the implications of the results of this study. 1.) The theoretical implications, based on the research model analyzed in this study, can strengthen theoretical concepts and provide support for previous research, literature that explains the influence of the role of work motivation in moderating the influence of organizational culture on motivation on organizational commitment and performance. employees who have strengthened their existence by theoretical concepts and the relationship between these variables. 2.) Managerial Implications, based on the results of the analysis that has been carried out, to improve the performance and commitment of employee organizations with moderation of work motivation can be done through improving organizational culture which will be able to increase the performance commitment of these employees. 


\section{International Journal of Business Economics (IJBE)}

Vol, 2 Issue 2, pp 86-98, March - August 2021

http://jurnal.umsu.ac.id/index.php/ijbe

eISSN 2686-472X

\section{CONCLUSION}

Based on the analysis and discussion of the research results, the writers concluded that the variable organizational culture has a positive and significant effect on employee organizational commitment. Organizational culture variables have a positive and significant effect on performance. Organizational commitment variable has a positive and significant effect on performance. Organizational commitment mediates the influence of organizational culture on performance and motivation does not moderate the influence of organizational culture on performance by showing a positive but insignificant effect. Writers provide suggestions that might benefit the parties involved in this study, namely that the company should carry out each function of organizational culture well, so that a better work environment can be created. The commitment of each employee must be further improved, in order to achieve the achievements of the company targets. The performance of every employee who always gives their performance very well is given a reward, as a sign that the company appreciates the performance that has been given to the company. It is better if the work motivation of the boss is increased again, such as supervision and attention to employees who work for company goals.

\section{REFERENCES}

Adhan, M., Jufrizen, J., Prayogi, M. A., \& Siswadi, Y. (2020). Peran Mediasi Komitmen Organisasi pada Pengaruh Kepuasan Kerja terhadap Kinerja Dosen Tetap Universitas

Swasta di Kota Medan. Jurnal Samudra Ekonomi dan Bisnis, 11(1), 1-15.

Andayani, I., \& Tirtayasa, S. (2019). Pengaruh Kepemimpinan, Budaya Organisasi, Dan Motivasi Terhadap Kinerja Pegawai. Maneggio: Jurnal Ilmiah Magister Manajemen, 2(1), 45-54.

Anggraeni, M. (2016). Kepuasan kerja Komitmen organisasi dan Turnover Intention di PT Hill Jaya Sakti. Skripsi pada Pogram sarjana S1 Ekonomi dan Bisnis, 1-29.

Bunga, N. J. (2012). Pengaruh Locus Of Control, Gaya kepemimpinan, dan Komitmen Organisasi Terahadap Kinerja Auditor. Accounting Analysis Journal, 1(1), 1-8.

Busro, M. (2018). Teori-Teori Manajemen Sumber Daya Manusia. Jakarta: Prenadamedia Group.

Dian, R. (2017). Pengaruh Persepsi dan Budaya Organisasi Terhadap Kinerja Pegawai dengan Motivasi Kerja Sebagai Variabel Moderasi. Jurnal Benefita, 2(3), 278-287.

Fauzi, M., Warso, M. M., \& Haryono, A. T. (2016). Pengaruh Budaya Organisasi dan Kepuasan Kerja Terhadap Kinerja Karyawan Dengan Komitmen Organisasi Sebagai Intervening. Journal of Management, 2(2), 1-15.

Fey, F. C., \& Denison, R. D. (2000). Organizational Culture and Effectiveness The Case of Foreign Firms in Rusia and Sweden. Journal Working Papper Servicess in Business Administration, 665-667.

Gultom, D. K. (2014). Pengaruh Budaya Organisasi Perusahaan Dan Motivasi Terhadap Kinerja Karyawan pada PT. Perusahaan Gas Negara (Persero) Tbk Medan. Jurnal Ilmiah Manajemen dan Bisnis, 14(2), 176-184.

Gusty, R., \& Seno, A. (2018). Pengaruh Budaya Organisasi Terhadap Kinerja Karyawan Dengan Komitmen Organisasi Sebagai Variabel Intervening (Studi Pada Hotel Mutiara Merdeka Pekanbaru). Jurnal JOM FISIP, 5, 1-12.

Hasibuan, M. S. (2003). Organisasi dan Motivasi Dasar Peningkatan Produktivitas. Jakarta: Bumi Aksara.

Hutomo, P. T. P., \& Akhmad, T. (2015). Pengaruh Gaya Kepemimpinan Budaya 


\section{International Journal of Business Economics (IJBE)}

Vol, 2 Issue 2, pp 86-98, March - August 2021

http://jurnal.umsu.ac.id/index.php/ijbe

eISSN 2686-472X

Organisasi, terhadap Kinerja Organisasi dengan Motivasi Kerja sebagai Variabel Moderasi Studi Empiris pada Dinas Pariwisata dan Kebudayaan di Kabupaten Jepara. Jurnal Ilmiah UNTAG Semarang, 1-17.

Jandeska, K., \& Maria, K. L. (2005). Womens Perceptions of Organizational Culture Work Attitudes and Role Modelling Behaviors. Journal of Managerial Issues, (4), 36-91.

Jufrizen, J. (2016). Efek Mediasi Kepuasan Kerja Pada Pengaruh Kompensasi Terhadap Kinerja Karyawan. Jurnal Ilmiah Manajemen dan Bisnis, 17(1).

Jufrizen, J. (2017). Efek Moderasi Etika Kerja Pada Pengaruh Kepemimpinan Transformasional dan Budaya Organisasi Terhadap Kinerja Karyawan. E-Mabis: Jurnal Ekonomi Manajemen dan Bisnis, 18(2), 145-158.

Jufrizen, J., Gultom, D. K., Sitorus, S. A., Sari, M., \& Nasution, M. I. (2018). The Effect of Organizational Culture and Islamic Work Ethic on Permanent Lecturers' Job Satisfaction, Organizational Commitment And Work Performance at Private Islamic Universities in the City of Medan. Proceeding 1st International Conference of Economic Studies (ICOES) 2018 (pp. 179-186).

Jufrizen, J., Lumbanraja, P., Salim, S. R. A., \& Gultom, P. (2017). The Effect of Compensation, Organizational Culture and Islamic Work Ethic Towards the Job Satisfaction and the Impact on the Permanent Lecturers. International Business Management, 11(1), 53-60.

Juliandi, A. (2018). Structural equation model based partial least square SEM-PLS Menggunakan SmartPLS. Jurnal Pelatihan SEM-PLS Program Pascasarjana Universitas Batam, 16-17.

Kadek, J. A., \& Widanaputra, W. (2017). Pengaruh Gaya Kepemimpinan Transformasional Dan Budaya Organisasi Pada Kinerja Organisasi Dengan Motivasi Kerja Sebagai Pemoderasi. E-Jurnal Akuntansi Universitas Udayana, 18(2), 15751603.

Kurniawan, M. (2013). Pengaruh Komitmen Organisasi Budaya Organisasi dan Kepuasan Kerja terhadap Kinerja Organisasi Publik Studi Empiris pada Skpd Pemerintah Kabupaten Kerinci. Jurnal Akuntansi, 1(3), 1-29.

Lina, D. (2014). Analisis Pengaruh Kepemimpinan dan Budaya Organisasi terhadap Kinerja Pegawai dengan Sistem Reward sebagai Variabel Moderating. Jurnal Riset Akuntansi dan Bisnis, 14, 77-97.

Mangkunegara, A. P. (2005). Pengaruh Motivasi terhadap kepusaan kerja pegawai BKKBN Kabupaten MUARA ENIM. Jurnal Manajemen dan Bisnis Sriwijaya, 3(6), $1-25$.

Mathis, L. R., \& Jackson, H. J. (2000). Human Resources Management. New Jersey: Prentice Hall.

Muis, M. R., Jufrizen, J., \& Fahmi, M. (2018). Pengaruh Budaya Organisasi Dan Komitmen Organisasi Terhadap Kinerja Karyawan. Jesya (Jurnal Ekonomi \& Ekonomi Syariah), 1(1), 9-25.

Nasution, M. I., Fahmi, M., Jufrizen, J., Muslih, M., \& Prayogi, M. A. (2020). The Quality of Small and Medium Enterprises Performance Using the Structural Equation ModelPart Least Square (SEM-PLS). Journal of Physics: Conference Series, 1477(2020), $1-7$.

Nurdin, S., \& Acep, R. (2016). Gaya Kepemimpinan Transformasional, Budaya Organisasi, Dan Kinerja Karyawan Dengan Mediasi Komitmen Organisasi. Ecodemica, 4(1), 1-15. 


\section{International Journal of Business Economics (IJBE)}

Vol, 2 Issue 2, pp 86-98, March - August 2021

http://jurnal.umsu.ac.id/index.php/ijbe

eISSN 2686-472X

Nystrom, P. C. (1993). Organizational Cultures Strategies and Commitments in Health Care Organizations. Journal Health Care Manage Review, 18, 43-49.

Pahmi, Idrus, \& Mahlia. (2011). Pengaruh Gaya Kepemimpinan danKepuasan Kerja terhadap Kinerja Pegawai melalui Komitmen Organisasi.

Parry, K. W., \& Thomson, S. B. P. (2003). Leadership, culture and performance: The case of the New Zealand public sector. Journal of Change Management, 3(4), 376.

Robbins, S. P., \& Judge, T. A. (2013). Organizational Behavior (15th ed.).

Soepardjo, T., \& Seno, D. (2014). Pengaruh Budaya Organisasi dan Komitmen Organisasi terhadap Kinerja Karyawan. Jurnal Ilmu Manajemen, 2(4), 1783-1793.

Sugiyono. (2010). Statistik Untuk Penelitian. Bandung: Alfabeta.

Sutarno, S. (2011). Pengaruh Lingkungan Kepemimpinan Transformasional Dan Budaya Organisasi Terhadap Kinerja Pegawai Yang Dimoderasi Motivasi Kerja. Jurnal Manajemen Sumberdaya Manusia, 5(1), 76-88.

Suwardi, \& Utomo, J. (2011). Pengaruh Motivasi Kerja Kepuasan Kerja dan Komitmen Organisasional terhadap Kinerja Pegawai. Jurnal Analisis Manajemen, 5(1).

Tarjono, T., \& Asep, D. (2018). Pengaruh Budaya Organisasi Terhadap Kinerja Personel Yang Dimediasi Oleh Komitmen Organisasi Pada Sekolah Pembentukan Perwira Lembaga Pendidikan Dan Pelatihan Polri Sukabumi. Jurnal Ekonomak, 4(3), 1-18.

Taurisa, C. M., \& Ratnawati, I. (2012). Analisis Pengaruh Budaya Organisasi Dan Kepuasan Kerja Terhadap Komitmen Organisasional Dalam Meningkatkan Kinerja Karyawan (Studi pada PT. Sido Muncul Kaligawe Semarang). Jurnal Bisnis dan Ekonomi (JBE), 19(2), 170-187.

Widyastuti, P., \& Hasan, F. (2015). Pengaruh Budaya Organisasi Dan Pengalaman Kerja Terhadap Kinerja Karyawan Dengan Motivasi Kerja Sebagai Moderating Pada Koperasi Pegawai Pln Sektor Priok, 1(1), 1-14. 